\title{
Pulses in the eastern margin current and warmer water off the north west European shelf linked to North Sea ecosystem changes
}

\author{
Philip C. Reid ${ }^{1, *}$, N. Penny Holliday ${ }^{2}$, Tim J. Smyth ${ }^{3}$ \\ ${ }^{1}$ Sir Alister Hardy Foundation for Ocean Science, 1 Walker Terrace, The Hoe, Plymouth PL1 3BN, United Kingdom \\ ${ }^{2}$ Southampton Oceanography Centre, European Way, Southampton SO14 3ZH, United Kingdom \\ ${ }^{3}$ Remote Sensing Group, Plymouth Marine Laboratory, Prospect Place, Plymouth PL1 3DH, United Kingdom
}

\begin{abstract}
The North Sea ecosystem has recently undergone dramatic changes, observed as altered biomass of individual species spanning a range of life forms from algae to birds, with evidence for an approximate doubling in the abundance of both phytoplankton and benthos as part of a regime shift after 1987. Remarkably, these changes, in part recorded in the Phytoplankton Colour Index of the Continuous Plankton Recorder (CPR) survey, are notable as episodic shifts occurring in 1988/89 and 1998 imposed on a gradual decadal trend. These biological events are shown to be a response to coincident changes in oceanic input and water temperature. Geostrophic transports have been calculated from a hydrographic section across the Rockall Trough, and a time series of seasurface temperature derived from satellite observations. The 2 pulses of oceanic incursion into the North Sea in circa 1988 and 1998 coincided with strong northward advection of anomalously warm water at the edge of the continental shelf.
\end{abstract}

KEY WORDS: North Sea $\cdot$ Regime shift $\cdot$ Plankton $\cdot$ Long-term changes $\cdot$ Shelf edge current $\cdot$ Remote sensing $\cdot$ SST $\cdot$ NAO

Resale or republication not permitted without written consent of the publisher

Understanding causes of changes in the circulation of the North Atlantic (Dickson 1997, Curry et al. 1998, Koltermann 1999, Turrell et al. 1999) over the last few decades is a priority issue because of potential forcing by climate change (Wood et al. 1999). Events are largely synchronous with the dominant mode of atmospheric behaviour, the North Atlantic Oscillation NAO (Reid et al. 1998b, Mork \& Blindheim 2000), that in 1988 moved into a period with the highest positive index for more than a century. The move to a positive NAO has been linked to a regime shift in the North Sea eco-

\footnotetext{
*E-mail: pcre@wpo.nerc.ac.uk
}

system that coincided with an increased incursion of oceanic water into the basin (Reid et al. 2001), and was followed in 1989 by the occurrence of a plankton species not seen there since 1911 (Lindley et al. 1990). A second large incursion took place in 1998, again associated with the presence of the same species, normally found in more southerly latitudes (Edwards et al. 1999).

The North Atlantic Ocean has experienced changes in temperatures in the last 2 decades on scales ranging from a general basin-wide increase to local positive or negative anomalies. Levitus et al. (2000) has shown that the heat content of the top $300 \mathrm{~m}$ of the world's oceans has markedly increased since the mid-1950s, and in the North Atlantic temperature anomalies have remained strongly positive since 1987, with the greatest maximum (>3 SD above the 1948 to 1998 mean) in 1998. Hansen \& Bezdek (1995) demonstrated the development of a strong positive temperature anomaly also starting in 1987 off Gibraltar that extended and intensified through 1990 to the north and south. The spread of this anomaly off Europe coincides with the position of the eastern boundary current.

The mechanisms contributing to the step-wise ecosystem changes that occurred after 1987 in the North Sea are still poorly understood. Are the changes reflecting increased northerly advection (Holliday \& Reid 2001) of warm water in the eastern boundary current? To address these issues we have assembled long-term evidence from the Continuous Plankton Recorder (CPR) survey, remotely-sensed sea-surface temperature, and subsurface temperature and salinity and associated geostrophic flow calculations from a section across the Rockall Trough.

Methods. CPR survey: Continuous Plankton Recorders (CPRs) have been towed behind voluntary merchant 
ships at a depth of $\sim 7 \mathrm{~m}$ on their normal routes since 1931. The survey is unique in that the methodology and plankton analysis procedures for $\sim 400$ taxa and a visual index of chlorophyll (phytoplankton colour) have been maintained with little change for more than $50 \mathrm{yr}$ (Warner \& Hays 1994). The plankton is caught on a moving band of silk of $270 \mu \mathrm{m}$ mesh, and each analysed sample represents a tow of approximately 10 nautical miles. The CPR was primarily designed to sample zooplankton, and because of the mesh size most phytoplankton pass through. However, as many diatoms and dinoflagellates form chains, have associated mucilage, or become entrapped in the fibrils of the silk, a large number of cells are retained. Many of the smaller flagellates disintegrate in the formalin preservative, but their chloroplasts may also contribute to the green colouration of the silk. Comparisons between CPR samples and in situ fluorescence suggests that CPR results give a semi-quantitative index of phytoplankton abundance.

Satellite SST: Sea-surface temperatures (1982 to 1999) from the Multi-Channel Sea Surface Temperature (MCSST) data set, which is derived from the 5channel Advanced Very High Resolution Radiometer (AVHRR) on board the NOAA series polar-orbiting satellites, have been processed for the NE Atlantic (40 to $60^{\circ} \mathrm{N}, 30^{\circ} \mathrm{W}$ to $20^{\circ} \mathrm{E}$, blocking out data from the Baltic and Mediterranean) with an $18 \mathrm{~km}$ resolution. A monthly mean was produced for each pixel in the domain, and then the departure from that mean was calculated for each pixel for each month of the time series, to remove any seasonal cycle. The data were then smoothed using a nearest-neighbour median filter with a 4 data-point window, to produce the plot in Fig. 1. A similar approach was applied to the NASA AVHRR Pathfinder data (9 $\mathrm{km}$ resolution) for the period 1987 to 1998 along the $200 \mathrm{~m}$ isobath between 40 and $61^{\circ} \mathrm{N}$ (see Fig. 2).

Rockall Trough hydrographic section: The Rockall Trough time series consists of seasonally-to-annually occupied standard full-depth CTD stations (1975 to 2000). For each complete occupation of the section, the total geostrophic transport relative to a level of no motion at 1200 dbars was calculated. Current meter records provide evidence of a mid-depth level of no motion, and analysis of the bottom water trapped by topography suggests error levels of 0.5 Svendrup, $\left(1 \mathrm{~Sv}=10^{6} \mathrm{~m}^{3} \mathrm{~s}^{-1}\right)$ due to the choice of the reference pressure (Holliday et al. 2000).

Results. A new analysis (Fig. 1) of north east Atlantic AVHRR sea-surface temperature (SST) confirms the general pattern of temperature anomalies presented by Hansen \& Bezdek (1995), demonstrating a period of high positive anomalies from 1987 to 1990, and a second period starting in 1995 to 1999 with low negative

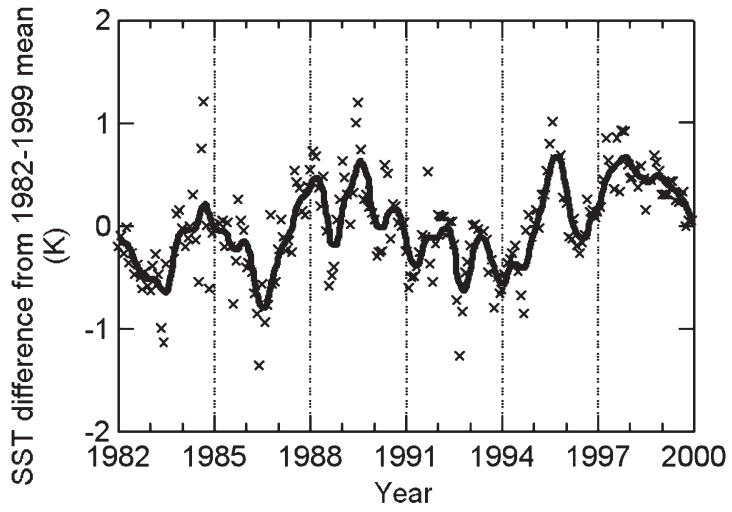

Fig. 1. Satellite-retrieved sea-surface temperature (SST) for the north east Atlantic from the MCSST data set showing difference $\left({ }^{\circ} \mathrm{K}\right)$ from the 1982 to 1999 mean

anomalies in 1983, 1986, 1992 and 1993/94. In Fig. 2, AVHRR SST observations are plotted for a $9 \mathrm{~km}$ wide band along the shelf edge, approximating the $200 \mathrm{~m}$ contour (the path of the shelf-edge current). While the general pattern found in the basin-wide series is still seen, more localised changes are evident including marked variability in the persistence of anomalies from south to north. Strong positive anomalies are seen to extend from south to north in 1989/90 and 1995/96, with an especially strong anomaly in late 1997 to early 1998. In contrast, a strong negative anomaly, especially in the south, was centred on the winter of 1993/94.

Hydrographic time series (subsurface temperature and salinity), taken from a section across the Rockall Trough (see Fig. 2), reveal, on the basis of geostrophic transport calculations (Holliday et al. 2000), that the strength of the northward flow of the eastern margin current (including the shelf edge current) fluctuates on interannual timescales. These measurements show unusually strong northward transport in the Rockall Trough during 1988/89 and 1998 (Fig. 3). The mean transport across the section is $3.7 \mathrm{~Sv}$, peaking at $7.9 \mathrm{~Sv}$ in 1989 and $7.5 \mathrm{~Sv}$ in 1998. Similar calculations of northward transport in the shelf edge current off Norway, with pronounced peaks in 1987, 1988 and 1996, were made as part of a study of Atlantic inflow into Nordic Seas between 1955 and 1996 (Mork \& Blindheim 2000). The measurements do not describe the total flow since the shelf edge current is mainly driven by the poleward density gradient; however, the calculations suggest that the current was more energetic during the above periods. While manifested at the surface by fronts and temperature and chlorophyll changes, the maximum flows in the shelf edge current occur at 200 to $300 \mathrm{~m}$. In the second half of 1995, the SST increases shown in Fig. 2 were also reflected by 

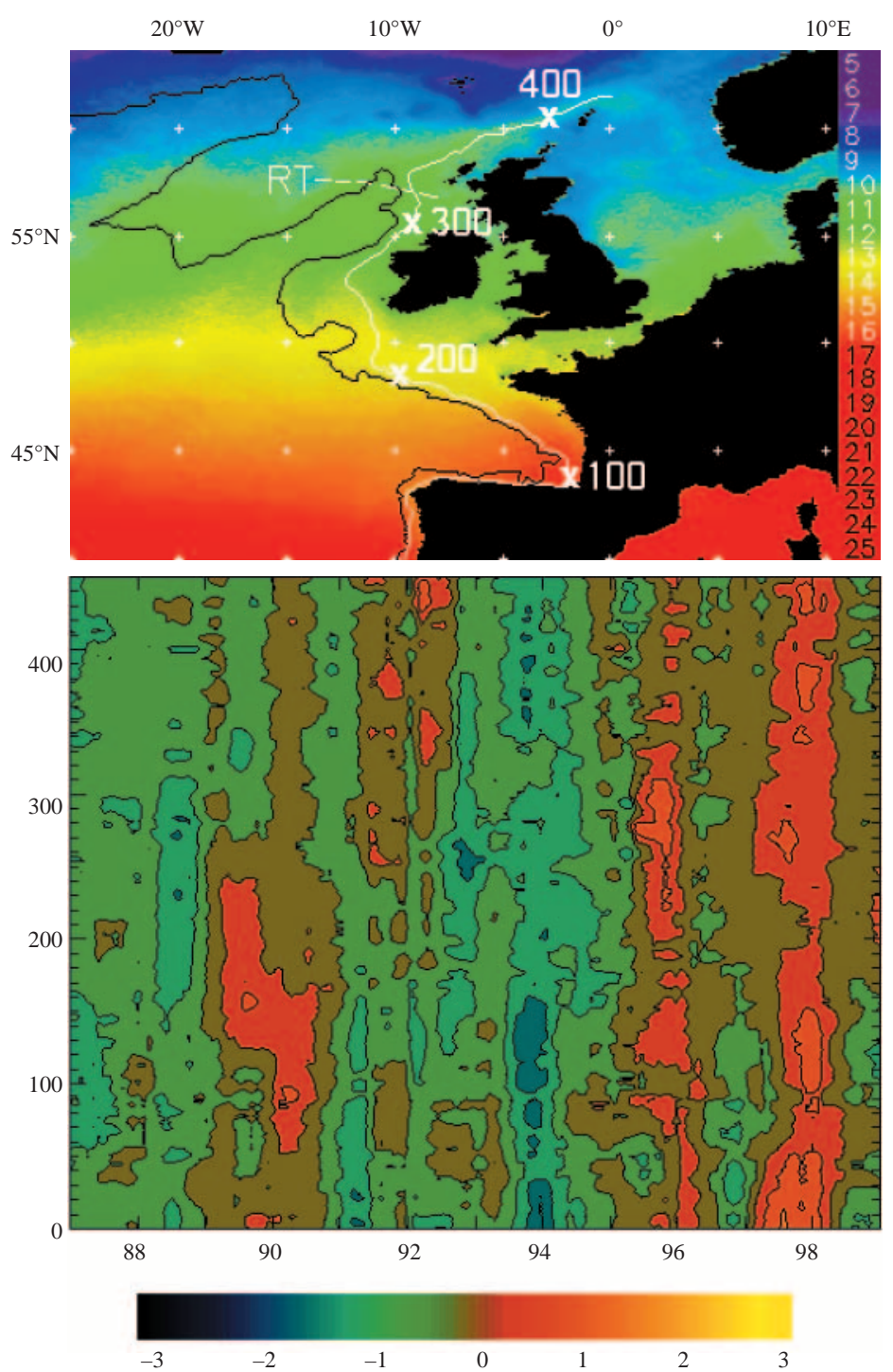

Fig. 2. Top: Mean sea-surface temperature (K) for NE Atlantic, from 'Pathfinder' dataset (1987 to 1999), with position of Rockall Trough transect (RT, dashed line), $2000 \mathrm{~m}$ isobath (black line) and $200 \mathrm{~m}$ isobath (white line); marked on $200 \mathrm{~m}$ isobath is the location from south to north of every 100th $9 \mathrm{~km}^{2}$ pixel along the shelf edge. Bottom: subset of same dataset as an anomaly plot of monthly averaged sea-surface temperature (1987 to 1999) in a band of adjacent pixels along the $200 \mathrm{~m}$ isobath to $61^{\circ} \mathrm{N}$ ( $y$-axis, north top, south bottom) and months/years ( $x$-axis)

a period of increasing temperature in the top $800 \mathrm{~m}$ of the Rockall Trough. After relatively stable temperatures since 1975, the upper ocean temperatures showed a positive anomaly (over the 1975 to 2000 mean) of $0.4^{\circ} \mathrm{C}$ in 1998 and as much as $0.5^{\circ} \mathrm{C}$ in February 2000.

Measurements of phytoplankton colour (a visual estimate of chlorophyll) from the CPR survey (Fig. 4) have been updated from Reid et al. (1998a). A stepwise increase in annual mean colour occurred after 1987 and has been maintained until at least 1999 at a

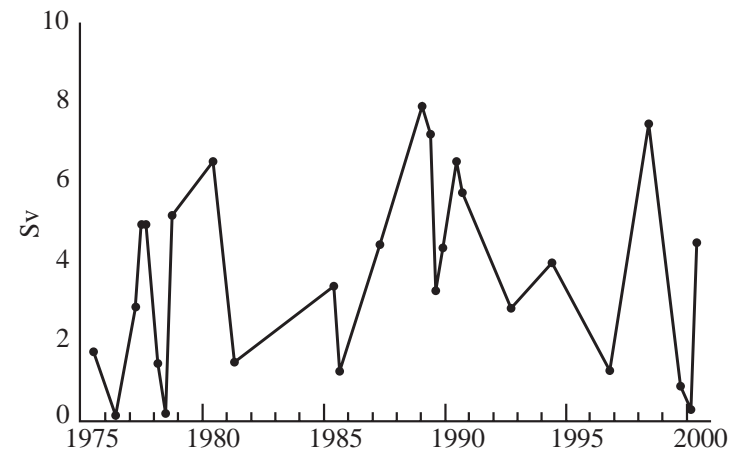

Fig. 3. Geostrophic transport of the upper $1200 \mathrm{~m}$ of the water column through the Rockall Trough from 1975 to 2000 (Holliday et al. 2000). $1 \mathrm{~Sv}=10^{6} \mathrm{~m}^{3} \mathrm{~s}^{-1}$; positive values northwards

level that is almost double the previous average. The changes are most pronounced in the winter and summer months and show peaks in 1988/89 and 1998. The upward trend in the summer until 1988 is partly a reflection of a change in timing, with the spring bloom gradually developing later and the autumn bloom earlier until circa 1988, when colour levels increased throughout the year over most of the North Sea.
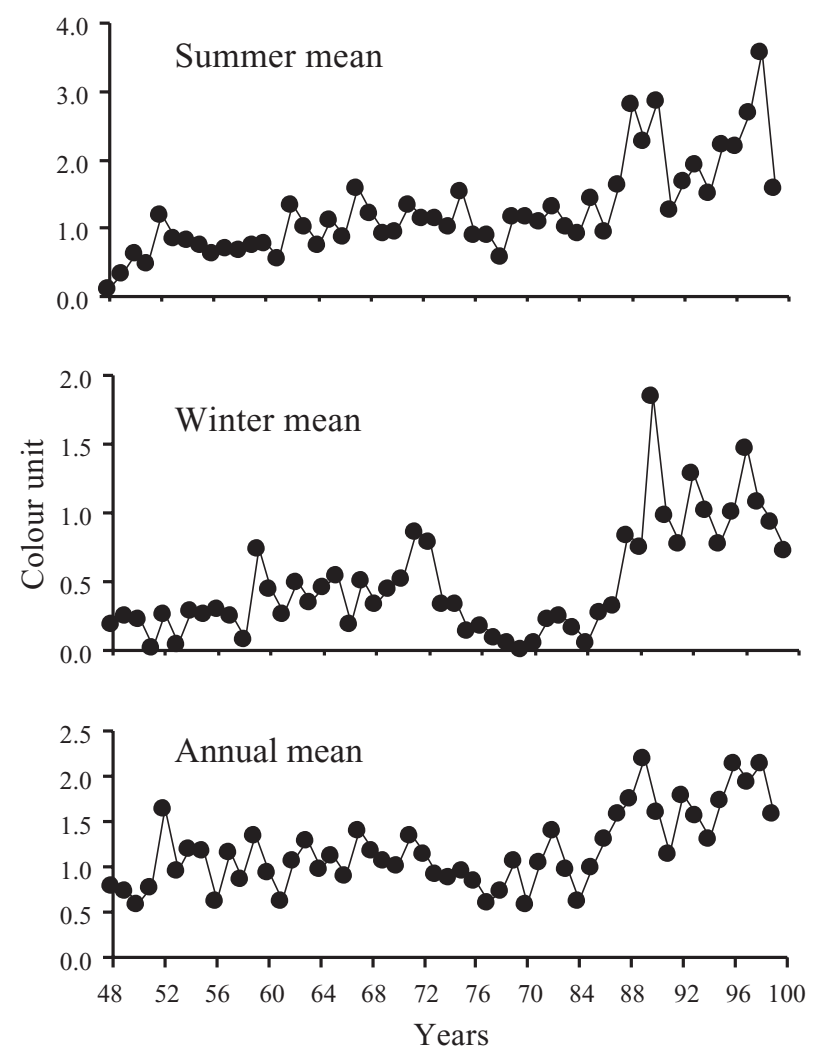

Fig. 4. Graphs of annual, winter (January to March) and summer (June to August) phytoplankton colour averaged for the Central North Sea based on the data used in Reid et al. (1998a) updated to 1999 
Discussion. A modelling study forced by observed wind fields has shown an increased inflow into the North Sea over the post-1987 period (Reid et al. 2001). Reid et al. (2001) proposed, on the basis of this increase in oceanic inflow and coincident pronounced changes in phytoplankton, zooplankton, fish and sea surface temperature, that a regime shift had occurred in the North Sea after 1987. The term 'regime shift' has been applied to abrupt changes in the abundance and composition of both plankton communities and fish stocks that may occur over large sea areas at decadal intervals. Most of these often step-like events appear to be associated with changes in regional hydrometeorological state, some may be caused by overfishing, while for others the forcing mechanisms are still unclear.

That this event affected the whole ecosystem is supported by evidence of a marked increase in the biomass of the benthos off the coast of the Friesian Islands at approximately the same time (Krönke et al. 1998). This combined evidence suggests that the North Sea has been more productive since 1987, largely as a consequence of an increased influx of oceanic water which is known to be the main source of nutrients (North Sea Task Force 1993). The peak in zooplankton in 1989 is a year later than that for phytoplankton, possibly reflecting a trophic lag and/or a direct response to the warmer waters of 1989/90.

The ecosystem of the North Sea is affected by numerous factors, including oceanic input, temperature, salinity, nutrient levels, river run-off, pollution and fishing activities. Superimposed on the regime shift, biological evidence and model studies point to unusually large inflows of oceanic water into the North Sea in 1988/89 and 1998. The 3 time series presented here indicate that these events occur when the shelf edge current is unusually energetic and during periods of significantly higher temperature. We propose that the North Sea changes are a response to episodic increased inflow, for the most part, of unusually warm oceanic water from the shelf edge current.

The mechanisms that convey oceanic water into the North Sea are not well understood (Huthnance 1995); factors other than the strength of the shelf edge current may be important. Timing of inflow events may also be influenced by local wind-driven advection. For example, while high flows were measured in the Norwegian shelf edge current in 1996 (Mork \& Blindheim 2000), the inflow to the North Sea in that year (on the basis of model calculations by Reid \& Planque 1999), was low, and southerly warm-water plankton did not penetrate into the basin. This reduction in flow is thought to be a consequence of the pronounced reversal of the NAO and its effect on local winds in the winter of 1995/96. In contrast, in the winter of 1997/98, when the NAO was positive, the warm waters of the shelf edge again contributed southerly oceanic plankton to the North Sea.

Increased temperatures may have profound effects on some species, and may in part account for observed changes to the important North Sea copepod Calanus finmarchicus. This species prefers cold temperate conditions, overwinters in deep water off the shelf, and was in the past the dominant copepod in the northern North Sea. A strong negative correlation has been demonstrated between $C$. finmarchicus and the NAO in the North Sea (Fromentin \& Planque 1996); since 1995 this relationship has broken down (Planque \& Reid 1998). In 1996, when the NAO reversed, numbers of $C$. finmarchicus should have been very high, but they remained low and have continued to do so, and were the lowest on record in 1998. It has been suggested (Heath et al. 1999) that the breakdown in the correlation is due to a reduction in the volume and in the depth of the upper surface of Norwegian Sea deep water, resulting in unfavourable overwintering conditions. The exceptionally warm and strong northwarddirected shelf edge current since 1995 would have been a further barrier to the successful introduction of C. finmarchicus to the North Sea since 1995.

By utilising time series data from plankton and hydrographic surveys with remotely-sensed SST products, a new insight into the variability and effects of oceanic advection onto the north west European shelf has been made possible. The results have emphasised the importance of the eastern margin current as a source of oceanic water to the North Sea. Our work and the observations of others provide clear evidence that the inflow occurred at a much higher rate in 1988/89 and 1998. Inflows of oceanic water onto the shelf, bringing in exceptional oceanic plankton, nutrients and anomalously warm water, appear to be the dominant influence forcing change in the North Sea ecosystem.

Our results have important implications for monitoring, ecosystem management and the sustainable exploitation of living resources in the North Sea. The combined effects of long-range forcing, as in the shelf edge current, and local wind-forcing of advection into the North Sea complicates prediction. However, a modelling study (Paeth \& Hense 1999) suggests that the NAO is likely to remain positive for the next 4 decades. This implies that the current ecosystem regime in the North Sea is likely to remain in force in the foreseeable future. If this occurs, the altered patterns of fish distribution and the increasing presence and abundance of warmer-water species seen in recent years is likely to be reinforced. Conditions are likely to continue to be unfavourable for colder-water species such as the cod, reducing the likelihood of a recovery of its presently very depleted stock. The apparent high 
sedimentation rate to the benthos is also likely to continue, possibly leading to an increase in the stocks of demersal species.

The 2 pulses of oceanic incursion into the North Sea in circa 1988 and 1998 coincided in part with strong northward advection of anomalously warm water at the edge of the continental shelf. Our results appear to confirm a major role for the shelf edge current as a source for water inflow and in the fertilisation of the North Sea.

Acknowledgements. We wish to thank the contributors to the time series used in this paper and in particular the shipping companies, captains and crews that have towed CPRs, and to acknowledge the countries and agencies that support the CPR survey through the SAHFOS funding consortium. We are grateful to the NOAA/NASA Pathfinder and MCSST projects for the provision and maintenance of the global SST data, from which a subset was derived for use in the satellite SST retrievals.

\section{LITERATURE CITED}

Curry RG, McCartney MS, Joyce TM (1998) Oceanic transport of subpolar climate signals to mid-depth subtropical waters. Nature 391:575-577

Dickson R (1997) From the Labrador Sea to global change. Nature 386:649-650

Edwards M, John AWG, Hunt HG, Lindley JA (1999) Exceptional influx of oceanic species into the North Sea late 1997. J Mar Biol Assoc UK 79:737-739

Fromentin JM, Planque B (1996) Calanus and environment in the eastern North Atlantic. 2. Influence of the North Atlantic Oscillation on Calanus finmarchicus and C. helgolandicus. Mar Ecol Prog Ser 134:111-118

Hansen DV, Bezdek HF (1995) On the nature of decadal anomalies in the North Atlantic sea surface. J Geophys Res 101:8749-8758

Heath MRR, Backhaus JO, Richardson K, McKenzie E, Slagstad D, Beare D, Dunn J, Gallego A, Hay S, Jónasdóttir S, Hainbucher D, Madden H, Mardalijevic J, Schlacht A (1999) Climate fluctuations and the spring invasion of the North Sea by Calanus finmarchicus in the North Sea. Fish Oceanogr 8 (Suppl 1):163-176

Holliday NP, Reid PC (2001) Is there a connection between high transport of water through the Rockall Trough and ecological changes in the North Sea? ICES J Mar Sci

Holliday NP, Pollard RT, Read JF, Leach H (2000) Water mass

Editorial responsibility: Otto Kinne (Editor),

Oldendorf/Luhe, Germany properties and fluxes in the Rockall Trough 1975-1998. Deep-Sea Res 47:1303-1332

Huthnance JM (1995) Circulation, exchange and water masses at the ocean margin: the role of physical processes at the shelf edge. Prog Oceanogr 35:353-431

Koltermann KP, Sokov AV, Tereschenkov VP, Dobroliubov SA, Lorbacher K, Sy A (1999) Decadal changes in the thermohaline circulation of the North Atlantic. Deep-Sea Res 46: 109-138

Krönke I, Dippner JW, Heyen H, Zeiss B (1998) Long-term changes in macrofaunal communities off Norderny (East Frisia, Germany) in relation to climate variability. Mar Ecol Prog Ser 167:25-36

Levitus S, Antonov JI, Boyer TP, Stephens C (2000) Warming of the world ocean. Science 287:2225-2229

Lindley JA, Roskell J, Warner AJ, Halliday NC, Hunt HG, John AWG, Jonas TD (1990) Doliolids in the German Bight in 1989 - evidence for exceptional inflow into the North Sea. J Mar Biol Assoc UK 70:679-682

Mork AM, Blindheim J (2000) Variations in the Atlantic inflow to the Nordic Seas, 1955-1996. Deep Sea Res 47: 1035-1057

North Sea Task Force (1993) North Sea Quality Status Report 1993. Oslo and Paris Commissions, London and Olsen \& Olsen, Fredensborg, Denmark

Paeth H, Hense (1999) A climate change signals in the North Atlantic Oscillation. CLIVAR Exch 4:25-29

Planque B, Reid PC (1998) Predicting Calanus finmarchicus abundance from a climatic signal. J Mar Biol Assoc UK 78: 1015-1018

Reid PC, Planque B (1999) Long-term planktonic variations and the climate of the North Atlantic. In: Mills D (ed) The ocean life of Atlantic salmon. Fishing News Books, Oxford, p 153-169

Reid PC, Edwards M, Hunt HG, Warner AJ (1998a) Phytoplankton changes in the North Atlantic. Nature 391:546

Reid PC, Planque B, Edwards M (1998b) Is observed variability in the long-term results of the Continuous Plankton Recorder Survey a response to climate change? Fish Oceanogr 7:282-288

Reid PC, Borges MF, Svendsen E (2001) A regime shift in the North Sea circa 1988 linked to changes in the North Sea horse mackerel fishery. Fish Res 50:163-171

Turrell WR, Slesser G, Adams RD, Payne R, Gillibrand PA (1999) Decadal variability in the composition of Faroe Shetland Channel bottom water. Deep Sea Res 46:1-25

Warner AJ, Hays GC (1994) Sampling by the Continuous Plankton Recorder survey. Prog Oceanogr 34:237-256

Wood RA, Keen AB, Mitchell JFB, Gregory JM (1999) Changing spatial structure of the thermohaline circulation in response to atmospheric $\mathrm{CO}_{2}$ forcing in a climate model. Nature 401:508

Submitted: October 4, 2000; Accepted: February 20, 2001 Proofs received from author(s): May 15, 2001 